\title{
Nutrient intake and economic analysis of young bulls reared in silvopastoral systems with babassu palm trees in the Pre-Amazon region
}

\author{
Consumo de nutrientes e análise econômica de tourinhos recriados em sistemas \\ silvipastoris compostos por palmeiras de babaçu na região Pré-Amazônia
}

\author{
ARAÚJO, Ricardo Alves de ${ }^{1 *}$; RODRIGUES, Rosane Claudia ${ }^{2}$; COSTA, Clésio dos \\ Santos $^{1}$; SANTOS, Francisco Naysson de Sousa ${ }^{3}$; ANDRADE, Alex Carvalho ${ }^{4}$; \\ SILVA, Ivone Rodrigues da ${ }^{5}$; JESUS, Ana Paula Ribeiro de ${ }^{2}$; CUTRIM JUNIOR, José \\ Antônio Alves ${ }^{6}$
}

\footnotetext{
${ }^{1}$ Universidade Federal do Ceara, Centro de ciências Agrárias, Departamento de Zootecnia, Fortaleza, Ceará, brasil.

${ }^{2}$ Universidade Federal do Maranhão, Centro de Ciências Agrárias e Animais, Departamento de Zootecnia, Chapadinha, Maranhão, Brasil.

${ }^{3}$ Universidade Federal da Paraíba, Centro de Ciências Agrárias, Departamento de Zootecnia, Areia, Paraíba, Brasil.

${ }^{4}$ Universidade Estadual do Piauí, Centro de Ciências Agrárias, Departamento de Agronomia, Parnaíba, Piauí, Brasil.

${ }^{5}$ Universidade Federal do Piauí, Centro de Ciências Agrárias, Teresina, Piauí, Brasil.

${ }^{6}$ Instituto Federal de Educação, Ciência e Tecnologia do Maranhão, São Luís, Maranhão, Brasil.

*Endereço para correspondência: ricardo_zoo@ hotmail.com
}

\section{SUMMARY}

This study evaluated the intake of dry matter (IDM), nutrients and the economic analysis of F1 young bulls from the cross between Nellore and Guzera on pastures of Urochloa brizantha cv. Marandu in silvopastoral systems composed of babassu palm (Attalea speciosa) and Marandu monoculture in the Pre-Amazon region of the state of Maranhão. Animals were evaluated in four systems consisting of 0,80 , 131,160 palms ha $^{-1}$, characterizing monoculture (MC), low density of palm trees (LDP), average density of palm trees (ADP) and high density of palm trees (HDP) during the rainy (RP) and dry (DP) periods. The dry matter intake, in $\mathrm{g} \mathrm{day}^{-1}$, $\% \mathrm{BW}$ and $\mathrm{g} \mathrm{kg}^{-0.75}$ was influenced by the densities of babassu palm trees $(\mathrm{P}<0.05)$. In both evaluation periods, the animals kept on monoculture consumed more forage. Animals kept on HDP consumed greater amounts of CP in both periods, approximately 478.20 and $599.18 \mathrm{~g} \mathrm{day}^{-1}$ for DP and RP, respectively. The intake of NDF was affected by periods and palm densities $(\mathrm{P}<0.05)$. There was a higher intake of $\mathrm{NDF}$ for animals kept on $\mathrm{MC}$, in both periods.
Of the four systems evaluated, only LDP resulted in a revenue per hectare higher than the costs, making it the only profitable system. However, in a five-year simulation, all systems resulted in an internal rate of return higher than $6,87 \%$ the rate of attractiveness, and the LDP system had the best result. All analyzed systems had a benefit/cost ratio greater than one; i.e., all are economically viable.

Keywords: Amazon, cattle, fiber, grass, shading

\section{RESUMO}

Objetivou-se avaliar o consumo de matéria seca (CMS), nutrientes e a análise econômica de tourinhos F1 do cruzamento de Nelore com Guzerá em pastagens de Urochloa brizantha cv. Marandu em sistemas silvipastoris compostos por palmeiras de babaçu (Attalea speciosa) e em monocultivo na região Pré-Amazônica Maranhense. Os animais foram avaliados em quatro sistemas, sendo $0,80,131,160$ palmeiras $\mathrm{ha}^{-1}$, caracterizando monocultura (MC), baixa 
densidade de palmeiras (BDP), média densidade de palmeiras (MDP) e alta densidade de palmeiras (ADP) durante os períodos chuvoso (PC) e seco (PS). O consumo de MS expresso em $\mathrm{g} \mathrm{dia}^{-1}, \% \mathrm{PV}$ e $\mathrm{g} \mathrm{kg}^{-0,75}$ foram influenciados pelas densidades de palmeiras de babaçu $(\mathrm{P}<0,05)$. Em ambos os períodos de avaliação, os animais mantidos no sistema de monocultura consumiram mais forragem. Os animais mantidos no sistema de ADP consumiram maiores quantidade de PB em ambos os períodos de avaliação, cerca de 478,20 e 599,18 g dia $^{-1}$ para o PS e PC, respectivamente. O consumo de FDN foi influenciado pelos períodos e densidades de palmeiras $(\mathrm{P}<0,05)$. Observaram-se maiores CFDN para os animais mantidos na MC, em ambos os períodos. Dos quatro sistemas avaliados, somente o BDP apresentou uma receita por hectare maior que os custos, tornado assim o único sistema lucrativo, porém em uma simulação para cinco anos, todos os sistemas apresentaram um valor de Taxa Interna de Retorno superior a $6,87 \%$ da taxa de atratividade, e o sistema de BD apresentou melhor resultado comparativamente aos demais. Todos os sistemas analisados tiveram a relação Benefício/custo maior que um, ou seja, todos são viáveis economicamente.

Palavras-chave: Amazônia, bovinos, fibra, forragem, sombreamento

\section{INTRODUCTION}

Brazil is one of the largest producers of beef cattle in the world. Currently, meat production supplies an increasing domestic consumption and exportable surplus enough to ensure the leadership of the country in beef exports relative to the rest of the world. Despite the significant numbers of the Brazilian beef cattle, there is still a lack of management tools such as strategic planning to assist in the definition of targets to be met and optimization of existing resources to raise profitability through control of costs and expenses, estimation of revenues and qualification of the manpower.
In addition to these factors, inadequate pasture management leads most monocultures of cultivated grasses to degradation, making the system less effective. An alternative to overcome this situation is the use of silvopastoral systems, which besides favoring the soil and plant, assists in the comfort of the animals, providing a higher yield (ARAÚJO et al., 2017).

The improvement of the system when using silvopastoral systems can be both productive and economic, since there is the possibility of extra income coming from the same area or even due to the higher performance of the animals, and consequently greater economic return to property.

In view of the above, and considering the importance of agriculture and farming activities for all Brazilian regions and, specifically, for the development of the state of Maranhão, which has one of its main economic activities in agribusiness (beef and dairy farming and agriculture), this study aimed to evaluate the influence of different densities of babassu palm trees in agroforestry systems on the nutrient intake and economic and financial performance of F1 Nellore x Guzerá cattle in the rearing phase compared to monoculture considering the production costs and the desired profitability.

\section{MATERIAL AND METHODS}

The experiment was conducted at ÁguaViva farm, in the municipality of Matinha-Baixada Maranhense region, with geographical position $45^{\circ} 00^{\prime} 40.9^{\prime \prime}$ W longitude and $03^{\circ} 06^{\prime} 55.5^{\prime \prime} \mathrm{S}$ latitude. Forage species used was Urochloa brizantha cv. Marandu and the arboreal specie babassu palm 
Attalea speciosa Martius which was already established on the property.

Animals (Nelore x Guzerá with average of $180 \pm 15 \mathrm{~kg}$ ) were evaluated in four systems being Marandu grass monoculture and three densities of babassu palms trees more Marandu grass, corresponding to $0,80,131$, and 160 palms $\mathrm{ha}^{-1}$, respectively. These systems characterize monoculture (MC), low density (LDP), average density (ADP) and high-density palm trees (HDP). Animals were placed on experimental units in completely randomized design (CRD) with subdivided plots arrangement, getting on the plots the densities of palms and in the subplots the rainy and dry seasons.
The data were grouped in two periods: the rainy season (April to June/July 2013) and dry season (June/July2013 to October 2013). Data regarding the average monthly rainfall calculated from a data series of 30 years and rainfall and temperature during the experimental period are in Figure 1. The annual precipitation varied around $2,000 \mathrm{~mm}$ annually, with the greatest concentration during the experimental period between the months of April to June. The maximum and the minimum temperatures were around 32 and $23^{\circ} \mathrm{C}$, respectively. Data were grouped into two periods: rainy season (April to June/July 2013) and dry season (June/July 2013 to October 2013).

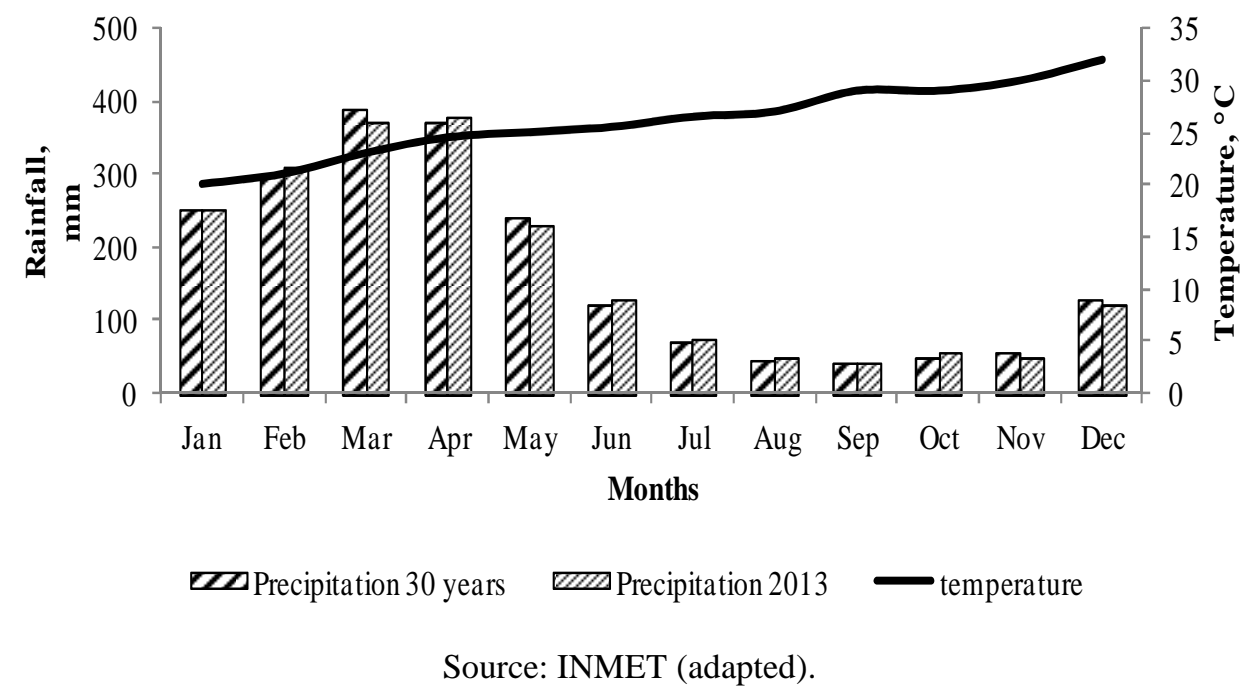

Figure 1. Average monthly rainfall calculated from a data series of 30 years and observed monthly rainfall and temperature during the experimental period in the year of 2013

The total area used in the experiment was eight hectares, subdivided into four paddocks of two hectares, managed under continuous stocking, with five Nellore x Guzera per experimental unit, which were the test animals; i.e., these animals were considered the minimal load supported per paddock. Over time, regulators animals were placed and removed of each paddock to avoid possible sub or super grazing, and directly monitored weekly by controlling the pasture height. Herbage allowance was estimated based on material 
harvested from a $0.25-\mathrm{m}^{2}$ square at 10 points per hectare and for the height, 50 points per hectare. The remainder of animals was kept in a reserve paddock (6 ha) and used in the experimental units as regulators animals, whenever there was need of stocking rate adjustment to keep the pastures to the predetermined height of $35 \mathrm{~cm}$. Gimenes et al. (2011) proposed that the most adequate management strategy corresponds to a height of $25 \mathrm{~cm}$. However, given the possible occurrence of etiolation of the grass in silvopastoral systems, we chosen to work with a greater height, aiming to prevent low herbage allowances. All animals received water and mineral mixture ad libitum, and health management as recommended by Embrapa beef cattle.
Before the establishment of the experiment samplings were made for characterization of soil fertility in the 0 $20 \mathrm{~cm}$ layer. As can be observed in Table 1, all paddocks presented soil with characteristics of average fertility and independent of the treatment, were performed the corrections of soil acidity on the basis of the data of the analysis performed by lifting method of base saturation to $70 \%$. The preparation of the area and corrective practices were carried out between October and November 2011, and the replanting of the grass in open areas within the paddocks, where the soil was exposed (no grass), was conducted between the months of January and February of 2012.

Table 1. Soil chemical composition prior to the beginning of experiments in the four pasture systems evaluated

\begin{tabular}{|c|c|c|c|c|c|c|c|c|c|c|}
\hline \multirow{2}{*}{ System } & $\mathrm{pH}$ & M.O & $\mathrm{P}$ & $\mathrm{K}$ & $\mathrm{Ca}$ & $\mathrm{Mg}$ & $\mathrm{H}+\mathrm{Al}$ & $\mathrm{Al}$ & $\mathrm{B}$ & CTC \\
\hline & $\mathrm{CaCl}_{2}$ & \multicolumn{3}{|c|}{$\mathrm{g} \mathrm{dm}^{3-(1)}$} & \multicolumn{6}{|c|}{$\mathrm{mmol}_{\mathrm{c}} \mathrm{dm}^{3-(1)}$} \\
\hline $\mathrm{MC}$ & 4,8 & 23 & 21 & 32 & 17 & 6 & 42 & 2 & 19 & 68 \\
\hline LDP & 5,2 & 23 & 9 & 40 & 21 & 9 & 27 & 1 & 20 & 61 \\
\hline ADP & 5,0 & 22 & 23 & 26 & 22 & 10 & 42 & 2 & 20 & 77 \\
\hline HDP & 4,8 & 23 & 11 & 37 & 20 & 7 & 44 & 1 & 28 & 75 \\
\hline \multirow{2}{*}{ System } & \multicolumn{2}{|c|}{$\mathrm{V}$} & $\mathrm{S}$ & & & $\mathrm{Fe}$ & $\mathrm{Zn}$ & $\mathrm{Mn}$ & & $\mathrm{B}$ \\
\hline & & & \multicolumn{8}{|c|}{$\mathrm{mg} \mathrm{dm}^{3^{-(1)}}$} \\
\hline $\mathrm{MC}$ & & & 5 & \multicolumn{2}{|c|}{0.4} & 104 & 4.4 & 47.3 & & 0.19 \\
\hline LDP & \multicolumn{2}{|c|}{56} & 7 & \multicolumn{2}{|c|}{0.4} & 149 & 4.2 & 33.6 & & 0.20 \\
\hline ADP & \multicolumn{2}{|c|}{45} & 6 & \multicolumn{2}{|c|}{0.4} & 61 & 4.6 & 54 & & 0.20 \\
\hline HDP & \multicolumn{2}{|c|}{41} & 10 & \multicolumn{2}{|c|}{0.4} & 105 & 4.1 & 44 & & 0.28 \\
\hline
\end{tabular}

${ }^{(1)}$ Babassu palm density: $\mathrm{MC}=$ grass monoculture (no trees); LDP = low density (80 palms ha $\left.{ }^{-1}\right)$; ADP = average density $\left(131\right.$ palms ha $\left.^{-1}\right)$; HDP = high density $\left(160\right.$ palms ha $\left.^{-1}\right)$.

The fertilization in paddocks of monoculture, 80, 131 and 160 palms ha $^{-}$ 1 was as follow: nitrogen $(\mathrm{N})$ in the form of urea in 150, 150, 150 and 150 $\mathrm{kg} \mathrm{ha}^{-1}$, respectively; phosphorus $\left(\mathrm{P}_{2} \mathrm{O}_{5}\right)$ in the form of simple superphosphate in 100, 150, 100 and $100 \mathrm{~kg} \mathrm{ha}^{-1}$; Potash $\left(\mathrm{K}_{2} \mathrm{O}\right)$ in 60, 60, 60 and $60 \mathrm{~kg} \mathrm{ha}^{-1}$; and dolomite limestone in 1100, 270, 1550 and $1260 \mathrm{~kg} \mathrm{ha}^{-1}$. Fertilizer application was performed as recommended by CFSEMG (1999), adopting fertility levels suggested for medium-potential grasses. In spite of the variation observed in the soil analysis, especially in the phosphorus content, the values 
were within the ranges recommended for the applied doses. The phosphorus source was applied only once, at the implementation of the experiment. Potassium and nitrogen applications were split into three sessions that occurred immediately after the plotleveling mowing and the evaluation harvests.

Canopy height was measured weekly, with ruler graduated in centimeters, in 30 random points by paddock. The height of each point corresponded to the average height of the canopy around the ruler. Canopy height was measured with a graduated ruler from the soil level to the curvature of the last leaf, at 150 points per paddock.

Forage biomass assessment were held every 28 days. For determining the productivity of forage $(\mathrm{PF})$ representative samples of the paddocks were taken using squares of $0.25 \mathrm{~m}^{2}$. The squares were placed at random in representative points of grazing at the time of sampling and the plants contained within each square were cut low to the ground every 28 days. After weighting, samples were separated into morphological components leaves, stems and dead material.

These components were also dried in an oven and the proportion of each component was expressed as a percentage of the total weight. In possession of the proportions of each component in dry matter, it was determined the relationship leaf: stem ratio (LSR).

For the estimation of dry matter intake (DMI) only 20 of 40 animals were used, being five (repetitions) per system. Chromium oxide $\left(\mathrm{Cr}_{2} \mathrm{O}_{3}\right)$ was administered orally, with the help of a rubber pipe, straight into the esophagus in doses of $10 \mathrm{~g}$, once a day. The procedure was held for eight days, and in the first five it was obtained the balance of intake and excretion of the indicator, and from the sixth day samples of fresh feces were collected (around $300 \mathrm{~g}$ ) directly from the rectum of animals, so that there was no contamination with dried feces or soil. The first day sampling was at 4:00 pm, the second at noon and the last at 8:00 am, so performing three days of collection. Then the samples were frozen at $-8{ }^{\circ} \mathrm{C}$. After, the samples were homogenized, packed in aluminum dishes and pre-dried in oven of forced ventilation at $65{ }^{\circ} \mathrm{C}$ up to present the constant weight. Then, they were processed in mill type "Wiley" with $1 \mathrm{~mm}$ sieve and grouped in proportion to have the composite samples of each animal.

The chromium concentration was estimated using an atomic absorption spectrophotometer, as methodology described by AOAC (2003). Fecal total production was determined by the following equation proposed by (BERCHIELLI et al., 2005). Total feces production $\left(\mathrm{g} \mathrm{DM}\right.$ day $\left.^{-1}\right)=$ Amount of $\mathrm{Cr}_{2} \mathrm{O}_{3}(\mathrm{~g}) /$ Concentration of $\mathrm{Cr}_{2} \mathrm{O}_{3}$ in fecal $\mathrm{DM}\left(\mathrm{g} \mathrm{DM}^{-1}\right)$. The DMI was estimated by the following equation: DMI = Fecal production/(1 - IVDMD). For the calculation of the rate of recovery of fecal indicator, it was used the following equation: Rate of recovery $=($ Fecal production by indicator $x$ 100)/Fecal production by total collection. The calculation of recovery rate consisted on using data produced with total administered chrome and total excreted chrome, estimated by calculated fecal production (FPc).

When the intake was related to the body weight of the animals, we used the mean weight of the period as reference. During the evaluation of the voluntary intake, the forage selected by the animals was collected in the form of a simulated grazing in June and September 2013. In forage samples, we determined the DM content (method 934.01), organic matter (method 942.05), crude protein (method 954.01), according to AOAC (2003). For 
the neutral detergent fiber (NDF) analysis, the samples were treated with thermostable alpha-amylase, without the use of sodium sulfite and corrected for residual ash (MERTENS, 2002).

For the economic analysis, the profits were obtained by the difference between the final sale value of animals according to the prices of the arroba (approximately 15 kilos) of the fat ox, and the initial value (corrected by the price of the lean ox). With the system cost, we analyzed technical, zootechnical and economic indicators using Excel ${ }^{\circledR}$ spreadsheets. No statistical tests were applied on the data obtained in the economic analyses.

An economic analysis of the evaluated systems was carried out to determine whether or not the revenue generated by them would return the invested capital. In the economic analysis, the following indices were applied: net present value (NPV), internal rate of return (IRR), and benefit/cost ratio (B/C). Net present value was determined considering the effect of time on the monetary values (real values), using the market interest rate (opportunity cost of capital). It is the sum of all net revenues adjusted at an adequate discount rate, and it is calculated as follows:

$$
\mathrm{NPV}=\sum_{\mathrm{i}=1}^{\substack{\mathrm{FCi} \\(\mathrm{i}) /(1+\mathrm{j})^{\mathrm{i}}}}
$$

where $\mathrm{j}=$ discount rate; and $\mathrm{FCi}=$ cash flows in the period. For each treatment, IRR was calculated as the percentage return obtained over the invested amount, which was not yet recovered in an investment project. In other words, it is the percentage value that expresses the average annual profitability (return) on the capital put into the project during the entire project analysis scenario. Mathematically, IRR is the interest rate that makes the present value of cash inflows equal to the present value of the cash outflows of the investment project; i.e., the interest rate that makes the net present value equal to zero, which is calculated as follows:

$$
\text { IRR }=k \text {, such that } \sum_{i=1}^{n}(C F) /(1+j)^{\mathrm{i}}=0
$$

where $\mathrm{j}=$ discount rate; $\mathrm{CFi}=$ cash flows in the period. The benefit/cost ratio $(B / C)$ was adopted as a measure of efficiency, expressing the overall performance of all production factors.

$$
\mathrm{B} / \mathrm{C}=\Sigma \mathrm{Ri}^{0} / \Sigma\left(\mathrm{Ci}^{0}+\mathrm{I}\right)
$$

where $\mathrm{R}=$ revenue from year 0 to year $\mathrm{i} ; \mathrm{Ci}=$ costs from year 0 to year $\mathrm{i}$; and $\mathrm{I}$ = investment.

Initially the data were submitted to normality test (Crame-Von Misses) and scapular (Levene) and attended the assumptions, they were submitted to variance analysis by F-test. In the case of significant difference, comparison of averages was by SNK at 5\% probability. The statistical analyses were conducted with the PROC GLM from SAS 9.0 (2001), with the option of repeated measurements in time, characterized by periods of assessment in each season of the year.

\section{RESULTS AND DISCUSSION}

The DM intake, in $\mathrm{g} \mathrm{day}^{-1}, \% \mathrm{BW}$ and $\mathrm{g}$ $\mathrm{kg}^{-0.75}$, were influenced by the densities of babassu palm trees ( $\mathrm{P}<0.05)$. In both evaluation periods, the animals kept in the monoculture system consumed more forage, with values 7.410 and $6.820 \mathrm{~g}$ day $^{-1}$ during the DP and RP, respectively (Table 2). 
Table 2. Intake of dry matter by young bulls in silvopastoral systems with different densities of babassu palm trees and monoculture in the rainy and dry seasons

\begin{tabular}{|c|c|c|c|c|c|}
\hline \multirow{3}{*}{ Season } & \multicolumn{4}{|c|}{ Systems } & \multirow[b]{2}{*}{$\mathrm{CV}(\%)$} \\
\hline & $\mathrm{MC}$ & LDP & ADP & HDP & \\
\hline & \multicolumn{5}{|c|}{ Intake of DM $\left(\mathrm{g} \mathrm{day}^{-1}\right)$} \\
\hline Dry & $7,410^{\mathrm{Aa}}$ & $6,720^{\mathrm{Ab}}$ & $6,550^{\mathrm{Ac}}$ & $6,450^{\mathrm{Ac}}$ & \multirow{2}{*}{17.87} \\
\hline Rainy & $6,820^{\mathrm{Aa}}$ & $6,430^{\mathrm{Ac}}$ & $6,290^{\mathrm{Ad}}$ & $6,520^{\mathrm{Ab}}$ & \\
\hline \multicolumn{6}{|c|}{ Intake of DM (\%BW) } \\
\hline Dry & $2.76^{\mathrm{Aa}}$ & $2.53^{\mathrm{Ab}}$ & $2.45^{\mathrm{Ab}}$ & $2.36^{\mathrm{Ac}}$ & \multirow{2}{*}{15.85} \\
\hline Rainy & $2.54^{\mathrm{Aa}}$ & $2.42^{\mathrm{Ab}}$ & $2.36^{\mathrm{Ab}}$ & $2.39^{\mathrm{Ab}}$ & \\
\hline \multicolumn{6}{|c|}{ Intake of DM $\left(\mathrm{g} / \mathrm{kg}^{0.75}\right)$} \\
\hline Dry & $0.1119^{\mathrm{Aa}}$ & $0.1020^{\mathrm{Ab}}$ & $0.0992^{\mathrm{Ab}}$ & $0.0960^{\mathrm{Ab}}$ & \multirow{2}{*}{18.96} \\
\hline Rainy & $0.1030^{\mathrm{Aa}}$ & $0.0976^{\mathrm{Ab}}$ & $0.0952^{\mathrm{Ab}}$ & $0.0971^{\mathrm{Ab}}$ & \\
\hline
\end{tabular}

Means followed by different letters, uppercase in the same row and lowercase in the same column, are significantly different by Duncan's test $(\mathrm{P}<0.05)$.

The DMI values, in both periods, were higher than those recommended by the National Research Council (NRC, 2000), which recommends that young bulls of this category should consume, on average, 4,500 $\mathrm{g} \mathrm{DM} \mathrm{day}^{-1}$, and in general, for the DP, we observed DMI of 7,780 $\mathrm{g} \mathrm{DM}_{\mathrm{day}^{-1}}$ and for RP, 6,510 g DM day ${ }^{-1}$. Probably, the change in sward structure altered the grazing time of the animals (ARAÚJO et al., 2017). These changes can be observed in Figure 2. It can be seen that during RP, forage production in $\mathrm{MC}$ was practically equal to LDP, around 4,500 $\mathrm{kg} \mathrm{DM} \mathrm{ha}{ }^{-1}$, but the amount of stems in MC was lower than in LDP.

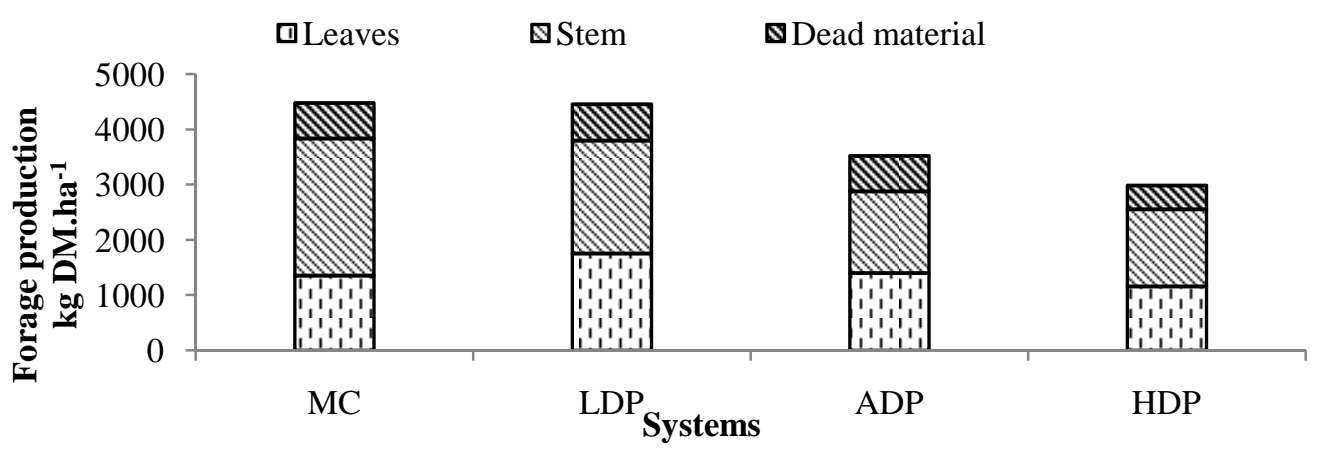

Figure 2. Forage production according to the amount of leaves and stems in silvopastoral systems and in monoculture during the rainy season

According to Cecato et al. (2000), as the animals select the most palatable parts of the grasses, usually the green leaves, the pasture presents an increasing proportion of non-preferential or rejected material, such as stems and dead/senescent material, during the period of occupation, making difficult the selection and consumption of forage, and as the amount of stems in LDP was higher, the IDM was negatively affected. On the other hand, the LDP and HDP presented lower consumption due to the lower availability of forage in the pasture as can be observed in the figure. 
As in RP, in DP, the animals kept on MC consumed larger amounts of forage $\left(6,820 \mathrm{~g} \mathrm{DM}\right.$ day $\left.^{-1}\right)$, followed by HDP animals $\left(6,520 \mathrm{~g} \mathrm{DM} \mathrm{day}^{-1}\right)$. Probably, the presence of the babassu at greater density created a more favorable microclimate, leading the cattle to increase the grazing time during the hotter hours of the day, that is, in the morning and afternoon, and this reflected in the IDM. It is interesting to observe that the production of forage in silvopastoral systems, during the DP, was basically the same as the MC production, with emphasis on the ADP system, but the increase in biomass occurred because of the grass stem lengthening, reflecting in the highest percentage of stems (Figure 3), due to the higher photosynthetic capacity of $\mathrm{MC}$, which caused the animals to consume more in this environment.

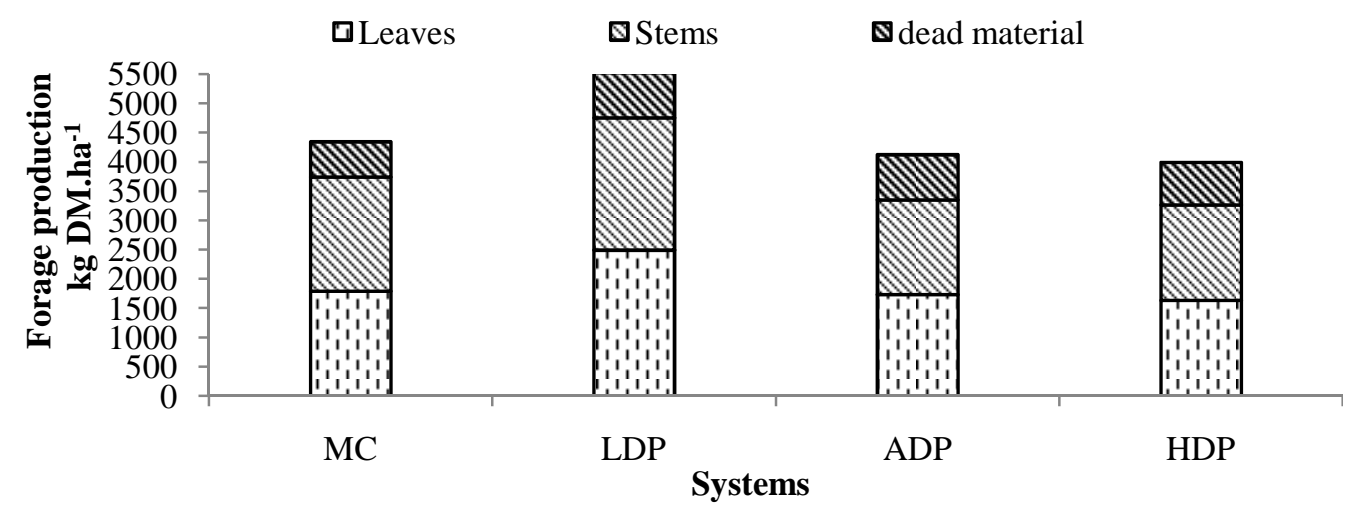

Figure 3. Forage production according to the amount of leaves and stems in silvopastoral systems and in monoculture during the dry season

When comparing IDM in $\% \mathrm{BW}$ and $\mathrm{g} \mathrm{kg}^{-}$ 0.75 , despite the lack of effect of the periods, there is a certain reduction in the intake from DP to RP, as nutritional requirements decrease with the maturing of the animals. One of the reasons for this lower intake based on body weight is the growth phase at which the animals were.

According to Owens et al. (1993), the growth of young bulls from birth under adequate environmental conditions is described as a sigmoid curve with two distinct phases, characterized by quite different trends. In the first phase, which corresponded to the beginning of the experiment, and therefore the DP, the growth is accelerated and, consequently, the animals presented higher forage intake due to the development of the bone and muscular tissues, activated by the release of the growth hormones thyroxine and somatotropin, resulting in a greater synthesis of muscle tissue in relation to adipose tissue. The second phase is characterized by a reduction in body growth intensity, with lower weight gain and greater deposition of adipose tissue, thus presenting lower IDM.

Therefore, forage supply did not negatively interfere with IDM, since in all pastoral systems and in both periods, the availability of DM was above the requirement based on the number of animals in each month, taking into account that according to Gomide et al. (2001), consumption is reduced when forage supply is within a range below 4$6 \%$ body weight. In this work, this critical availability range was not reached, since there was a rigorous control of the stocking rate. 
Cattle naturally concentrate grazing activities on frequently grazed areas, because of the nutrient density and absence of dead biomass in old stands that interferes with selection of green material. Therefore, management for quality involves heavy grazing, directed and in strategic times, to remove old, senescent, low quality forage. The ability of animals to harvest green material depends to some extent on the accessibility to the green material and that the selective ability is increased when the green material is physically more separated from the dead material, residual stems reduce grazing efficiency.
The effect for the IDM influenced the results in intake $\mathrm{CP}$, which have a direct relationship (P <0.05). There was influence of periods and densities (Table 3 ). The animals kept in the HDP system consumed higher amounts of CP in both evaluation periods, about 478.20 and $599.18 \mathrm{~g} \mathrm{day}^{-1}$ for DP and RP, respectively. During the DP, the lowest intake CP was due to the animals kept in the ADP (420.51 $\mathrm{g} \mathrm{day}^{-1}$ ). And in general, the highest intake of $\mathrm{CP}$ values occurred during the rainy season. There was no effect of either the densities or the periods on intake of $\mathrm{CP}$ when expressed in \% $\mathrm{BW}$ and $\mathrm{g} \mathrm{kg}^{-0.75}$.

Table 3. Crude protein intake (g.day ${ }^{-1}$, $\%$ BW and $\mathrm{g} / \mathrm{kg}^{0.75}$ ) by young bulls in silvopastoral systems with different densities of babassu palm trees and monoculture in the rainy and dry seasons

\begin{tabular}{|c|c|c|c|c|c|}
\hline \multirow{3}{*}{ Season } & \multicolumn{4}{|c|}{ Systems } & \multirow[b]{2}{*}{$\mathrm{CV}(\%)$} \\
\hline & $\mathrm{MC}$ & LDP & ADP & HDP & \\
\hline & \multicolumn{5}{|c|}{ CP intake $\left(\mathrm{g} \mathrm{day}^{1}\right)$} \\
\hline Dry & $470.72^{\mathrm{Bb}}$ & $450.91^{\mathrm{Bc}}$ & $420.51^{\mathrm{Bd}}$ & $478.20^{\mathrm{Ba}}$ & \multirow{2}{*}{19.25} \\
\hline Rainy & $525.82^{\mathrm{Ab}}$ & $487.39^{\mathrm{Ac}}$ & $495.65^{\mathrm{Ac}}$ & $599.18^{\mathrm{Aa}}$ & \\
\hline \multicolumn{6}{|c|}{$\mathrm{CP}$ intake $(\% \mathrm{BW})$} \\
\hline Dry & $0.18^{\mathrm{Aa}}$ & $0.17^{\mathrm{Aa}}$ & $0.16^{\mathrm{Aa}}$ & $0.18^{\mathrm{Aa}}$ & \multirow{2}{*}{13.45} \\
\hline Rainy & $0.20^{\mathrm{Aa}}$ & $0.18^{\mathrm{Aa}}$ & $0.19^{\mathrm{Aa}}$ & $0.22^{\mathrm{Ba}}$ & \\
\hline \multicolumn{6}{|c|}{ CP intake $\left(\mathrm{g} \mathrm{kg}^{0.75}\right)$} \\
\hline Dry & $0.0071^{\mathrm{Aa}}$ & $0.0068^{\mathrm{Aa}}$ & $0.0064^{\mathrm{Aa}}$ & $0.0071^{\mathrm{Aa}}$ & \multirow{2}{*}{15.20} \\
\hline Rainy & $0.0079^{\mathrm{Aa}}$ & $0.0074^{\mathrm{Aa}}$ & $0.0075^{\mathrm{Aa}}$ & $0.0089^{\mathrm{Aa}}$ & \\
\hline
\end{tabular}

Means followed by different letters, uppercase in the same row and lowercase in the same column, are significantly different by Duncan's test $(\mathrm{P}<0.05)$.

These data show the effect of shading on the nutritive value of grasses, because in the HDP system, the animals consumed little DM, but the content of $\mathrm{CP}$ in this type of environment is higher (ARAÚJO et., 2016a). In agreement with Moreira et al. (2009), the higher CP contents in the shaded plants are related to the larger cell size, which results in a higher cellular content and, consequently, higher $\mathrm{CP}$ contents. Another mechanism that can contribute to the higher intake of $\mathrm{CP}$ is related to the delay in the ontogenetic development of plants grown under the most intense shade. The quality of the forage is perhaps the most important factor influencing the productivity of grazing cattle. Forage plants provide energy, protein, minerals and vitamins to animals under free grazing, and during the rainy season this improvement is evident in tropical pastures used in silvopastoral systems (ARAÚJO et al., 2016b; RODRIGUES et al., 2015; 2016). Moura (2004) noted that in areas with large densities of babassu there was a negative linear effect of increasing density on protein content, indicating a 
possible competition for water and nutrients. Such effect did not happen in this work because the layout of palm trees at random may have interfered in this competition.

The NDF intake was influenced by periods and densities of palms $(\mathrm{P}<0.05)$. We observed higher fuel consumption for animals kept in $\mathrm{MC}$, in both periods (Table 4). During the DP, the animals of this system consumed 5,379.66 $\mathrm{g}$ NDF day $^{-1}$ and during the RP 4,762.40 $\mathrm{g}$ NDF day $^{-1}$, followed by the animals of the LDP during the RP and the animals of HDP during the DP.

Table 4. Neutral detergent fiber intake $\left(\mathrm{g}^{-\mathrm{day}^{-1}}, \% \mathrm{BW}\right.$ and $\mathrm{g} / \mathrm{kg}^{0.75}$ ) by young bulls in silvopastoral systems with different densities of babassu palm trees and monoculture in the rainy and dry seasons

\begin{tabular}{|c|c|c|c|c|c|}
\hline \multirow{3}{*}{ Season } & \multicolumn{4}{|c|}{ Systems } & \multirow[b]{2}{*}{$\mathrm{CV}(\%)$} \\
\hline & $\mathrm{MC}$ & LDP & ADP & HDP & \\
\hline & \multicolumn{4}{|c|}{ NDF intake $\left(\mathrm{g} \mathrm{day}^{-1}\right)$} & \\
\hline Dry & $5,379.66^{\mathrm{Aa}}$ & $4,757.08^{\mathrm{Ab}}$ & $4,473.65^{\mathrm{Ad}}$ & $4,549.18^{\mathrm{Ac}}$ & \multirow{2}{*}{21.34} \\
\hline Rainy & $4,762.40^{\mathrm{Ba}}$ & $3,852.21^{\mathrm{Bc}}$ & $4,386.64^{\mathrm{Ac}}$ & $4,456.42^{\mathrm{Ab}}$ & \\
\hline \multicolumn{6}{|c|}{ NDF intake $(\% \mathrm{BW})$} \\
\hline Dry & $2.01^{\mathrm{Aa}}$ & $1.79^{\mathrm{Ab}}$ & $1.68^{\mathrm{Ab}}$ & $1.67^{\mathrm{Ab}}$ & \multirow{2}{*}{19.87} \\
\hline Rainy & $1.78^{\mathrm{Aa}}$ & $1.45^{\mathrm{Ab}}$ & $1.64^{\mathrm{Ab}}$ & $1.63^{\mathrm{Ab}}$ & \\
\hline \multicolumn{6}{|c|}{ NDF intake $\left(\mathrm{g} / \mathrm{kg}^{0.75}\right)$} \\
\hline Dry & $0.0812^{\mathrm{Aa}}$ & $0.0722^{\mathrm{Aa}}$ & $0.0677^{\mathrm{Aa}}$ & $0.0677^{\mathrm{Aa}}$ & \multirow{2}{*}{22.32} \\
\hline Rainy & $0.0719^{\mathrm{Aa}}$ & $0.0585^{\mathrm{Aa}}$ & $0.0664^{\mathrm{Aa}}$ & $0.0664^{\mathrm{Aa}}$ & \\
\hline
\end{tabular}

Means followed by different letters, uppercase in the same row and lowercase in the same column, are significantly different by Duncan's test $(\mathrm{P}<0.05)$.

Variations in intake NDF seem to be related to the interaction of the percentage of shade with the maturity stage of the plant (PACIULLO et al., 2007). Under conditions of high shading, plants tend to stem lengthening with the advance of maturity, which may result in increases in forage fiber content. The stem lengthening is a strategy of the plant in which its height increases in search of luminosity, and this increase usually occurs by elongation of the stem. As can be verified in Figure 4, during the dry period, the height of the pastures was higher than in the rainy season, except for LDP.

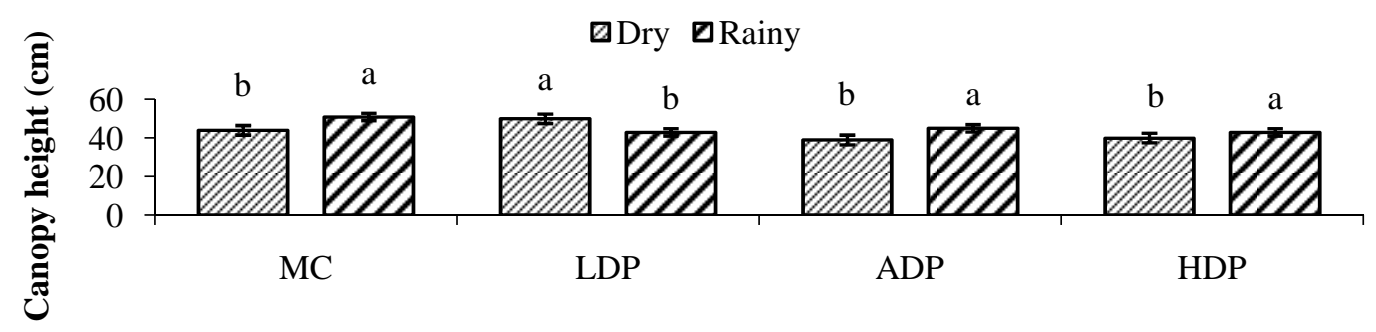

Sistems

Figure 4. Mean height of forage canopy in silvopastoral and monoculture systems during the experimental period of 2013. Equal letters indicate that there was no effect of periods over the height of the pasture 
Pastures maintained lower result in lower bite mass, forage intake and, consequently, lower animal performance. The animals seek to compensate for this reduction by increasing the number of bites per unit of time and increasing the time spent with the grazing activity, as stated by Araujo et al. (2017). According to Sousa et al. (2010), under natural shading conditions, Marandu grass has lignin less interspersed with hemicellulose and cellulose. In this situation, lignin has a higher proportion of syringaldehyde, a monomer that is less complexed with hemicellulose and cellulose than vanillin, thus characterizing a fiber of better nutritional quality.

Table 5 lists the values related to the costs with the implementation of the different systems. As there was an increase in the density of palm trees, the implementation costs increased. This is mainly due to the time spent with the use of machinery, because to deviate from the trees there is an increase in the hours paid for using the tractor, this represented more costs in the implementation of the HDP system.

Table 5. Costs with the implementation of the different silvopastoral systems composed of babassu palm trees and Marandu grass and monoculture of Marandu grass in the Pre-Amazon region of the state of Maranhão, Brazil

\begin{tabular}{|c|c|c|c|c|c|c|c|c|}
\hline \multirow{3}{*}{$\begin{array}{l}\text { Services and } \\
\text { inputs }^{1}\end{array}$} & \multicolumn{8}{|c|}{ Systems } \\
\hline & \multicolumn{2}{|c|}{$\mathrm{MC}$} & \multicolumn{2}{|c|}{ LDP } & \multicolumn{2}{|c|}{ ADP } & \multicolumn{2}{|c|}{ HDP } \\
\hline & $\left(\mathrm{R} \$ . h^{-1}\right)$ & $\%$ & $\left(\mathrm{R} \$ . \mathrm{ha}^{-1}\right)$ & $\%$ & $\left(\mathrm{R} \$ . h^{-1}\right)$ & $\%$ & $\left(\mathrm{R} \$ . \mathrm{ha}^{-1}\right)$ & $\%$ \\
\hline Plowing & 330 & 2.60 & 440 & 3.44 & 440 & 3.44 & 660 & 5.07 \\
\hline Seeds & 250 & 1.97 & 250 & 1.95 & 250 & 1.95 & 250 & 1.92 \\
\hline Drinking troughs & 150 & 1.18 & 150 & 1.17 & 150 & 1.17 & 150 & 1.15 \\
\hline Fences & 1500 & 11.83 & 1500 & 11.73 & 1500 & 11.73 & 1500 & 11.53 \\
\hline Fertilization & 450 & 3.55 & 450 & 3.52 & 450 & 3.52 & 450 & 3.46 \\
\hline Animals ${ }^{2}$ & 10000 & 78.86 & 10000 & 78.19 & 10000 & 78.19 & 10000 & 76.86 \\
\hline Total & 12680 & 100 & 12790 & 100 & 12790 & 100 & 13010 & 100 \\
\hline
\end{tabular}

${ }^{\mathrm{I}}$ Values in Brazilian Real, equivalent to U\$\$ 3,105 of the commercial dollar.

${ }^{2}$ Animals and C.M - Item consisting of the purchase of animals, sanitary treatment, manpower, troughs and management center (shade cloth, water fountain and salt trough).

Table 6 shows the technical and zootechnical indices used for economic evaluations. It was observed that in all systems, the mean daily gain was above $500 \mathrm{~g}$, and for animals reared exclusively on pasture, such as those observed in this study, it would allow a reasonable weight development for crossbred steers in the rearing phase.

The animals kept in BDP were those that had a higher gain (750 g.day $\left.{ }^{-1}\right)$, which due to the greater supply of forage resulted in a higher stocking rate in comparison to the other systems (2.20 $\left.\mathrm{UA} \mathrm{ha}^{-1}\right)$. Considering the weight of arroba in 2015, HDP animals started to be more valued, but over the period this system had the least valued animals ( $R \$$ 1,096.84). At the end of the evaluation period, the animals kept in LDP were the most valued (R\$ 1,159.40). 
Table 6. Technical and zootechnical indicators of rearing cattle in different silvopastoral systems composed of babassu palms and Marandu grass and monoculture of Marandu grass in the Pre-Amazon region of the state of Maranhão, Brazil

\begin{tabular}{|c|c|c|c|c|}
\hline \multirow{2}{*}{ Technical indicators } & \multicolumn{4}{|c|}{ Systems } \\
\hline & $\mathrm{MC}$ & LDP & ADP & HDP \\
\hline Initial body weight (kg) & $250 \pm 10.50$ & $251 \pm 11.30$ & $248 \pm 12.40$ & $253 \pm 13.20$ \\
\hline Mean daily gain $(\mathrm{kg})$ & 0.65 & 0.75 & 0.63 & 0.58 \\
\hline Final body weight (kg) & 328.00 & 341.00 & 323.60 & 322.60 \\
\hline Value of the initial live animal (R\$) & 850.00 & 853.40 & 843,20 & 860.20 \\
\hline Value of the final live animal (R\$) & 1115.20 & 1159.40 & 1100.24 & 1096.84 \\
\hline Stocking rate $\left(\mathrm{UA} \mathrm{ha}^{-1}\right)$ & 1.75 & 2.20 & 2.00 & 1.80 \\
\hline Produced arrobas & 26.25 & 34.50 & 30.00 & 27.00 \\
\hline
\end{tabular}

Period of 120 days. Arroba traded at the time of slaughtering at $\mathrm{R} \$ 102.00$.

The expression of the economic results by the monthly profitability allows to evaluate the financial return of the operation in relation to the invested capital (Table 7). It was considered that investment with fences and manpower was the same for all environments. Of the four systems evaluated, only the LDP had a higher per-hectare revenue (R\$ $2,550.68)$ than costs $(\mathrm{R} \$ 2,078.98)$, thus representing the only profitable system
( $\mathrm{R} \$ 471.70)$. The total monthly costs in the MC, ADP and HDP systems surpassed the revenues, so that, the balance between these components showed a loss of $\mathrm{R} \$ 127.38, \mathrm{R} \$ 78.50$ and $\mathrm{R} \$ 104.66$ per hectare, respectively. This clearly demonstrates that monoculture and shaded pasture systems in the experimental year were not an economically viable alternative.

Table 7. Financial indicators of rearing cattle in different silvopastoral systems composed of babassu palms and Marandu grass and monoculture of Marandu grass in the Pre-Amazon region of the state of Maranhão, Brazil

\begin{tabular}{|c|c|c|c|c|}
\hline \multirow{3}{*}{ Technical indicators } & \multicolumn{4}{|c|}{ Systems } \\
\hline & $\mathrm{MC}$ & LDP & ADP & HDP \\
\hline & \multicolumn{4}{|c|}{$\mathrm{R} \$$ hectare $^{-1}$} \\
\hline Total costs & 2078.98 & 2078.98 & 2078.98 & 2078.98 \\
\hline Total revenues & 1951.60 & 2550.68 & 2000.48 & 1974.31 \\
\hline Net profit & -127.38 & 471.70 & -78.50 & -104.66 \\
\hline \multicolumn{5}{|c|}{$\mathrm{R} \$ /$ hectare/month } \\
\hline Total costs & 519.74 & 519.74 & 519.74 & 519.74 \\
\hline Total revenues & 487.90 & 637.67 & 500.12 & 493.57 \\
\hline Net profit & -31.84 & 117.92 & -19.62 & -26.16 \\
\hline \multicolumn{5}{|c|}{ Sensitivity analysis (interest rate $=6,87 \%$ aa) } \\
\hline Benefit/cost ratio & 1.23 & 1.48 & 1.17 & 1.15 \\
\hline NPV $(\mathrm{R} \$)$ & 3803.2 & 5001.36 & 4300.96 & 3848.62 \\
\hline $\operatorname{IRR}(\%)$ & 7.21 & 8.97 & 7.67 & 7.35 \\
\hline
\end{tabular}


It is worth noting that the three systems that were not profitable cannot be considered inefficient, even because the evaluation lasted only three months, so the implementation costs of the systems had not been diluted yet, and for this, longer evaluations are required. The profitability of cattle management in pastures reaches $12.63 \%$ if considered the historical average of the arroba of the ox. However, if considering values for the arroba of the ox at certain times of the year, profitability may reach $39.46 \%$.

In accordance to Araújo et al. (2016a), the number of animals per area and the productivity of the land are indicators of intensification of the production system related to the technologies that save the land factor, more relevant in regions where the price of this factor is high, as well as where the ecosystem is more subjected to degradation as is the case of monoculture pastures. In conclusion alm tree density and the DMI affect the animal performance. The system LDP results in better animal performance and forage production over time, which increase the stocking rate and livestock production per area.

In a five-year simulation, the Net Present Value at the discount rate of $12 \%$ per annum adopted in this study and obtained for all evaluated system was positive. A system analyzed on the basis of NPV is economically viable when this index is greater than zero (SANTANA, 2005). All systems showed an IRR higher than $6,87 \%$. The LDP system had the best result in comparison with the others. All analyzed systems had a benefit/cost ratio greater than one; i.e., all are economically viable. The LDP system was highly attractive as an alternative profitable investment, while the other systems showed to be economically unviable during the first year of evaluation.

\section{ACKNOWLEDGMENTS}

The authors thank the Fundação de Amparo à Pesquisa e ao Desenvolvimento Científico $e$ Tecnológico do Maranhão (FAPEMA), for financing the project and providing science initiation scholarships to our program, the Conselho Nacional de Pesquisa (CNPQ) for the scientific initiation scholarships, and to the FOPAMA study and research group for the help in conducting the experiments.

\section{REFERENCES}

ARAÚJO, R.A.; RODRIGUES, R.C.; COSTA, C.S.; SANTOS, F.N.S.; CUTRIM JÚNIOR, J.A.A.; JESUS, A.P.R.; SHIGAKI, F.; ARAÚJO, J.S. Grazing behavior and spatial distribution of feces of Young bulls in silvopastoral systems and Marandu monoculture in the Pre-Amazon region. Acta Scientiarum, v.39, n.1, p.83-90, 2017.

ARAÚJO, R.A.; RODRIGUES, R.C.; COSTA, C.S.; LANA, R.P.; SANTOS, F.N.S.; LIMA, A.J.T, RODRIGUES, M.M. Forage intake and performance of cattle in silvopastoral systems and monoculture of Marandu in PreAmazon region. African Journal of Agricultural Research, v.11, n.20, p.1849-1857, 2016a.

ARAÚJO, R.A.; RODRIGUES, R.C.; COSTA, C.S.; SANTOS, F.N.S.; COSTA, F.O.; LIMA, A.J.T.; SILVA, I.R.; RODRIGUES, M.M. Chemical Composition and bromatologic degradability in situ of Marandu grass in silvopastoral systems formed by babassu and monoculture systems.

Revista Brasileira de Saúde Produção Animal [online], v.17, n.3, p.401-412, 2016 b. 
ASSOCIATION OF ANALYTICAL CHEMISTS - AOAC. Official

Methods of Analysis. 17th ed. 2nd rev. Gaithersburg, MD, 2003. 1094p.

BERCHIELLI, T.T.; OLIVEIRA, S.G.; CARRILHO, E.N.V.M.; FEITOSA, J.V.; LOPES, A.D. Comparison of markers used to estimate fecal production and digesta flow of cattle.

Revista Brasileira de Zootecnia, v.34, n.3, p.987-996, 2005.

CECATO, U.; MACHADO, A.O.; MARTINS, E.N.; PEREIRA, L.A.F.; BARBOSA, M.A.A.F.; SANTOS, G.T. Evaluation of Production and Any Physiological Characteristics of Genotypes of Panicum maximum Jacq. under two Cutting Heights. Revista Brasileira de Zootecnia, v.29, n.3 p.660-668, 2000.

COMISSÃO DE FERTILIDADE DO SOLO DO ESTADO DE MINAS GERAIS - CFSEMG. Recomendações para uso de corretivos e fertilizantes em Minas Gerais - $5^{\mathbf{a}}$ aproximação. Viçosa, MG: Universidade Federal de Viçosa, 1999. 359p.

GOMIDE, J.A.; WENDLING, I.J.; BRAS, S.P.; QUADROS, H.B. Milk Production and Herbage Intake of Crossbred Holstein x Zebu Cows Grazing a Brachiaria decumbens Pasture under two Daily Forage Allowances. Revista Brasileira de Zootecnia, v.30, n.4, p.1194-1199, 2001.

MERTENS, D.R. Gravimetric determination of amylase-treated neutral detergent fiber in feeds with refluxing in beakers or crucibles: collaborative study. Journal of AOAC International, v.85, n.6, p.1217-1240, 2002.
MOREIRA, G.R.; SALIBA, E.O.S.; MAURÍCIO, R.M.; SOUSA, L.F.; FIGUEIREDO, M.P.; GONÇALVES, L.C.; RODRIGUEZ, N.M. Evaluation of Brachiaria brizantha cv. Marandu in silvopastoral systems. Arquivo Brasileiro de Medicina Veterinária e Zootecnia, v.61, n.3, p.706-713, 2009.

MOURA, E.G. Agroambientes transition evaluated from the point of view of family agriculture between the Amazon and the Northeast, diversity and structure. In: Agroambientes of transition between the topic humid and semi-arid regions of Brazil: attributes, changes, use in household production. São Luís, MA: UEMA, 2004. p.15-51.

NATIONAL RESEARCH COUNCIL NRC. Nutrient requirements of beef cattle. 7th ed. Washington, DC: National Academy Press, 2000.

OWENS, F.N.; DUBESKI, P.; HANSON, C.F. Factors that alter the growth and development of ruminants. Journal Animal Science, v.71, n.11, p.3138-3150, 1993.

PACIULLO, D.S.C.; CARVALHO, C.A.B.; AROEIRA, L.J.M.; MORENZ, M.J.F.; LOPES, F.C.F.; ROSSIELLO,

R.O.P. Morphophysiology and nutritive value of signalgrass under natural shading and full sunlight. Pesquisa Agropecuária Brasileira, v.42, n.4, p.573-579, 2007.

RODRIGUES, R.C.; ARAÚJO, R.A.; COSTA, C.S.; LIMA, J.T.; OLIVEIRA, M.E.; SANTOS, F.N.S.; ARAÚJO, J.S.; SANTOS, V.M.; ARAÚJO, A.S.F. Soil microbial biomass in agroforestry system of Northeast Brazil. Tropical grasslands, v.3, n.1, p.41-48, 2015. 
RODRIGUES, R.C.; LIMA, A.J.T.;

ARAÚJO, R.A.; JESUS, A.P.R.;

COSTA, C.S.; SANTOS, F.N.S.;

COSTA, F.O.; CUTRIM JÚNIOR,

J.A.A.; SHIGAKI, F.; AZEVÊDO,

D.M.M.R. Agronomic, morphogenic

and structural characteristics of

Marandu grass in silvopastoral systems

composed of babassu palm and grass

monoculture. Semina: Ciências

Agrárias, v.37, n.4, p.2331-2342, 2016.

SANTANA, A.C. Elementos de

economia, agronegócio e

desenvolvimento local. Belém:

GTZ/TUD/UFRA, 2005. 197p.

STATISTICAL ANALYSIS SYSTEM.

SAS user's Guide: Statistics. Version

9.0. Cary, NC, USA: SAS Institute,

2001.

SOUSA, L.F.; MAURÍCIO, R.M.;

MOREIRA, G.R.; GONÇALVES, L.C.;

BORGES, I.; PEREIRA, L.G.R.

Nutritional evaluation of 'Braquiarão' grass in association with 'Aroeira' trees in a silvopastoral system. Agroforestry

System, v.79, n.2, p.189-199, 2010.

Receipt date: 05/02/2018

Approval date: 26/06/2018 
Errata

No artigo "Nutrient intake and economic analysis of young bulls reared in silvopastoral systems with babassu palm trees in the Pre-Amazon region", com número de DOI: 10.1590/S1519-99402018000300002, publicado no periódico Revista Brasileira de Saúde e Produção Animal, v.19, n.3, p.241-255 jul./set., 2018, na página 241:

Onde se lia:

"Alex Carvalho de Andrade".

Leia-se:

“Alex Carvalho Andrade"”. 
Errata

No artigo "Nutrient intake and economic analysis of young bulls reared in silvopastoral systems with babassu palm trees in the Pre-Amazon region", com número de DOI: 10.1590/S1519-99402018000200003, publicado no periódico Revista Brasileira de Saúde e Produção Animal, v.19, n.2, p. 166-177 abr./jun., 2018, na página 241:

Onde se lia:

"RODRIGUES, Ivone da Silva"

Leia-se:

"SILVA, Ivone Rodrigues da" 